\title{
THE EFFECT OF LEARNING CLIMATE ON INNOVATIVE WORK BEHAVIOR IN DIGITAL START-UP COMPANY
}

\author{
Niluh Zahwa Savitry ${ }^{\star 1}$, Marina Sulastiana ${ }^{2}$, Nurul Yanuarti ${ }^{3}$ \\ Universitas Padjadjaran, Indonesia*123 \\ niluh13002@mail.unpad.ac.id ${ }^{* 1}$, marina.sulastiana@unpad.ac.id ${ }^{2}$ \\ nurul.yanuarti@.unpad.ac.id ${ }^{3}$
}

\begin{abstract}
Along with the fast development of technology, makes computers, robots, and automatization are usually used in the business. This phenomenon makes the competition quite strict for the digital start-up, which provides services in corporate systems. Therefore, a company, an IT-based company, in particular, requires innovation and development. This research aims to analyze the effect of learning climate on innovative work behavior in digital start-up companies. This research used a simple linear regression method with a measuring instrument, namely The Dimensions of Learning Organization Questionnaire and Innovative Work Behaviour. This research was conducted on 102 employees. The result shows that learning climate affects the innovative work behavior in $51 \%$ of employees in the company, and the rest $49 \%$ are affected by other variables outside this research.
\end{abstract}

Keywords: Digital Start-Up; Innovative Work Behavior; Learning Climate

\section{INTRODUCTION}

The development of technology marked with Industrial Revolution 3.0, which has changed a new work pattern using computers and robots. Moreover, on June 28, 2020 , the Industry Minister has launched a roadmap of Industrial Revolution 4.0. It is a technological change that has been discussed by the world community for a long time. The automatization concept in some corporations applies with fast development from the emerge of the internet and digital technology. It is commonly called a smart factory. With that concept, the method for data collection and exchange is faster and more efficient online. Thus, it requires an internet network and website or application-based system.

The automatic system grows and brings start-up which is engaged in the field of application and technology. The business needs to meet the market need by developing a decent product, service, or innovative platform. This organization also grows in Indonesia; there are at least 1,500 developing local start-up companies, as cited by Daily Social (2017).

Digital start-up company is one of the companies engaged in application development service, Android, iOS, etc. This company has provided service for (1) Mobile Apps Developer (development of mobile application on Android, iOS, Symbian, JayaMe); (2) Web Apps Developer (development in business or company in the form of a website for specific need); (3) Custom Software Development (development of software or platform as required by company or institution). The unpredictable technology development makes this company have to survive and compete with similar companies. It needs to show optimal, adequate performance for the customers. It requires sufficient human resources, particularly employees working agilely and have the innovative spirit to realize these objectives.

In making new ideas, processes, products, and procedures in an organization or company, it can be identified from work behavior as shown by employees. One of the work behaviors which affect the renewal behavior is Innovative Work Behaviour (IWB). The effect interprets in the context of a particular method in facilitating the initiation achievement and intentional recognition from ideas, process, product, or procedure, which is new and useful (Ayuni, 2018). 
In their most recent study, Jong \& Hartog (2010), found that IWB consists of four stages related to each other: problem recognition, idea generation, promotion idea, and idea realization. The two first activities from the phases of problem recognition and idea generation are work behavior, while the last two steps are oriented from an idea that has been made (Jong \& Hartog, 2010). Another study implies that individuals who are willing to make innovation and expand their contribution outside their work scope can make innovation flow that is sustainable in the company (Parker \& Turner, 2006).

Referring to these theories, IWB is an essential behavioral aspect to be owned by employees in a company, mainly digital start-up which grows and faces a challenge in the competition of technology start-up business. Based on information in the field, this company requires innovation and business development since it only has two original products that still in development. Meanwhile, some competitor companies have more than two products that are constantly developed following the customer need.

In Jong \& Hartog, 2010), IWB is a result of interaction between capability owned by an individual and the condition of a system in the environment. IWB is based on the individual's potency, consisting of intellectual capacity and psychological condition with interacts with system condition in the environment. The interaction process between individual potency and system condition in this environment will encourage IWB.

The result of some researches shows antecedents related to the environmental system, which is applicable in the organization. It affects the forming of IWB, namely organizational climate (Farrell et al, 2017), organizational support for innovation (Scott \& Bruce, 1994), and innovation strategy (Jong \& Hartog, 2010). Meanwhile, in the individual phase, some antecedents which form IWB are Educational Level (Hartjes, 2010), Creative Behaviour (Series et al, 2017), Psychological Capital (Series et al., 2017), and Self Efficacy (Luthans et al, 2007).

Learning climate variable will measure the result of interaction with the environment. The broad outline variable refers to the individual perception of a company's organizational activity, which supports and allows them to create, obtain, and transfer knowledge and get involved in learning behavior, such as inquiry, dialogue, collaboration, and vision development. Therefore, when they are applied well from the employees' perspective, a company can have a good learning climate. Based on these problems, this research aims to analyze the effect of learning climate on innovative work behavior in this digital start-up company. Hypotheses of this research are as follows:

$\mathrm{HO}$ : There is no significant effect between learning climate and innovative work behavior in Digital Start-up Company employees.

$\mathrm{H} 1$ : There is a significant effect between learning climate and innovative work behavior in Digital Start-up Company employees.

About the learning climate, a controversial issue frequently discussed in researches related to climate is the interpretation of the construct itself and how to operate it in the organization. Some studies related to organizational climate prove urgency to research organizational climate effectively, so research results can better meet development requirements. Nowadays, research on organizational climate is frequently focused on organizational climate, specifically, not in general.

Schneider and Reichers (1983, in Ayuni 2018) stated for the first time that without referring to certain climate specifications (motivation climate, service quality climate, innovation climate, and so on), measurement about organizational climate would be less measured. Context of organizational climate, which is too broad, makes the research incapable of describing the researcher's organizational climate concept as expected.

In another perspective, in Eldor \& Harpaz (2018), the learning climate comes from the company's atmosphere. It means that learning climate is a perception of the employees concerning how the company's existence can encourage learning in 
supporting their work. In other words, an organization provides a forum for the employees to expand their skill and share it with other employees. It is considered the best way to achieve the organizational purpose (Eldor \& Harpaz, 2018).

Eldor \& Harpaz (2018) stated five dimensions of learning climate as follows. First, Continuous Learning Opportunity. This dimension measures the learning process designed in work, aiming to make someone capable of learning continuously from their work. Second, Inquiry and Dialogue. What inquiry and dialogue mean is employees' perception about company activities to make someone get used to asking the question, stating their opinion to a co-worker, and giving feedback to the idea related to their work. The Third is Collaboration and Team Learning. This dimension's meaning is the employees' perception of corporate activities intended to make someone capable of learning and working in a group and making collaboration a part of learning. It shows that learning can be from interaction resulted from the co-worker. The fourth dimension is empowering people toward a collective vision. This dimension explains the employees' perception of their involvement to achieve its collective vision and learn its part. And the last dimension is learning from the leader This dimension explains the employees' perception of the leader's involvement as a role model in their whole learning activities.

There are some definitions of Innovative Work Behaviour (IWB), as stated by Farr and Ford in Jong \& Hartog (2010), IWB as an individual's behavior that aims to achieve the initiation and intentional introduction (within a work role, group, or organization) of new and useful ideas, processes, products, or procedures. Innovative Work Behaviour is individual behavior that aims to achieve initiation and recognition of an idea, process, product, and procedure that are new and useful. Initiation and recognition of ideas, strategy, development, and procedure can be in the scope of a work role, group, and organization. In Jong \& Hartog (2010) IWB is the result of interaction between input and capability owned by an individual and the condition of the system applicable in a unique environment. In the beginning, IWB will be from potency owned by an individual, but psychological condition and interaction system in the environment also contribute to the emergence of IWB. Without a system that supports the environment, innovation potency in an individual will be challenging to appear.

Jong \& Hartog (2010) stated that innovative work behavior could relate to stages from the innovation process itself, namely opportunity exploration, idea generation, championing, and application. The first dimension is Opportunity Exploration. Opportunity usually starts with the discovery of the gap between actual and ideal work performance. In this dimension, employees are encouraged to understand the workplace's problem and requirement, which creates an opportunity to change through the improvement process. In opportunity exploration, the innovation process occurs when workers start finding new idea opportunity (Krueger, 2000). Opportunity can be found through some methods, by finding anomaly which causes the change in work pattern, development of problem to work method, the emergence of new work demand and technology change in the work process.

The second is the Idea Generation. Idea Generation is innovation behavior in employees as shown in action which develops innovation by creating and suggesting a creative idea for a new product, method, and service. Idea generation will come when employees can direct their behavior in searching for opportunity and information into a unity of concept.

The third dimension is Championing. An innovation is vulnerable to resistance, mainly when innovation is related to tasks or a new method. When ideas are proposed, people who receive them will explore how these ideas will affect them or their function. Therefore, it is essential to have a strong coalition in realizing innovation. Through championing, the innovator will seek to establish a partnership to realize their innovation 
idea (Loefianti, 2015). Championing includes behavior that relates to the search for support and coalition, inviting and affect other employees and negotiate with them (Loefianti, 2015).

The last dimension of IWB is Application. This phase frequently requires an individual to change an idea into a practical plan to be realized. Application means to do what is necessary to transform an idea into reality, including behavior to develop a new product or process and its test and modification (Loefianti, 2015).

\section{METHODS}

This research used a quantitative descriptive methodology with primary data collection technique through a questionnaire. The subject of this research was the whole population (102 respondents) from employees who have worked for at least three months. The measuring instrument used to measure the learning climate in this research was the Dimension of Learning Organization Questionnaire (DLOQ) (Eldor \& Harpaz, 2018). The measuring instrument consisted of 30 items in the form of a Likert scale with an assessment range of 1-5, with a self-assessment filling method.

The test process for this measuring instrument was conducted on 30 employees. The measuring instrument's validity test was conducted through the expert judgment method and Pearson Product Moment Correlation in every item with the total item score. The validity test results in every item were obtained by calculating Corrected item-total Correlation and the significant rate of 0.005 . Meanwhile, the reliability test was conducted through the discrimination power test of Cronbach's alpha item. The result of Cronbach's alpha test shows the reliability value of $\alpha=0.925$. Thus, based on the test result, a measuring instrument of learning climate is valid and reliable for taking research data. The blueprint of the measuring instrument after the test is shown below.

\section{Table 1. Blueprint of Measuring Instrument Dimension of Learning Organization} Questionnaire (DLOQ)

\begin{tabular}{lc}
\hline \multicolumn{1}{c}{ Dimension } & Item Quantity \\
\hline Continuous Learning Opportunity & 7 \\
Inquiry and Dialogue & 7 \\
Collaboration and Team Learning & 6 \\
Empowerment toward a Collective Vision & 4 \\
Learning from Leaders & 6 \\
\hline
\end{tabular}

Source: Eldor \& Harpaz (2018)

The measuring instrument of Innovative Work Behaviour The researcher performed adaptation and modification processes to adjust items in the measuring instrument made (Jong \& Hartog, 2010). The measuring instrument consisted of 24 items in form of a Likert scale with an assessment range of 1-5, with the self-assessment filling method. The test process for this measuring instrument was conducted on 30 employees. The measuring instrument's validity test was achieved through the expert judgment method and Pearson Product Moment Correlation in every item with the total item score. The validity test result shows that every item's score was above $r$ table with a significant rate of 0.005 . Meanwhile, the reliability test was conducted through the discrimination power test of Cronbach's alpha item. The result of Cronbach's alpha test shows the reliability value of $\alpha=0.925$. Thus, based on the test result, a measuring instrument of Innovative Work Behavior is stated to be valid and reliable to be used in the process of taking research data. The blueprint of the measuring instrument after the test is shown below. 
Table 2. Blueprint of Measuring Instrument for Innovative Work Behavior

\begin{tabular}{lc}
\hline \multicolumn{1}{c}{ Dimension } & Item Quantity \\
\hline $\begin{array}{l}\text { Opportunity } \\
\text { Exploration }\end{array}$ & 4 \\
\hline Idea Generation & 4 \\
\hline Championing & 4 \\
\hline Idea & 4 \\
Implementation & \\
\hline
\end{tabular}

Source: Jong (2010)

\section{RESULTS AND DISCUSSION}

The data collection process was conducted population in this company from several divisions and positions. The research was conducted on 102 respondents with profile as follows:

Table 3. Employee Profile

\begin{tabular}{|c|c|}
\hline Category & Frequency $(\mathrm{N}=102)$ \\
\hline \multicolumn{2}{|l|}{ Gender } \\
\hline Male & 84 \\
\hline Female & 18 \\
\hline \multicolumn{2}{|l|}{ Age } \\
\hline $20-25$ & 46 \\
\hline $26-30$ & 40 \\
\hline $30-35$ & 9 \\
\hline$>35$ & 7 \\
\hline \multicolumn{2}{|l|}{ Employee Status } \\
\hline Contract & 10 \\
\hline Permanent & 82 \\
\hline \multicolumn{2}{|l|}{ Education } \\
\hline Senior High School/Vocational High School & 20 \\
\hline Diploma Program & 10 \\
\hline Bachelor Program & 70 \\
\hline Postgraduate Program & 2 \\
\hline
\end{tabular}

Before making a regression model, the classical assumption test was conducted first, so the model provided an estimated BLUE (Best, Linear, Unbiased, and Estimator). This assumption test consisted of two tests, namely normality and linearity tests. Result of normality test was significance rate in two variables which have been determined, namely 0.05 . In learning climate, normality test provided score of $0.111(p=0.111 ; p>$ $0.05)$ and innovative work behavior variable, $0.178(p=0.178 ; p>0.05)$.

Concerning the linearity test, the significant rate of linearity among learning climate variables shows the result of 0.000 . In the test result, a significance of less than 0.05 $(0.00<0.005)$ shows a linear relationship between the learning climate variable and innovative work behavior. Thus, based on the data, it can conclude that the assumption of normality and linearity met in two research variables, so they have met the linear regression test requirement.

This research hypothesizes that learning climate positively and significantly affects the Innovative Work Behaviour in digital start-up employees. Linear regression analysis test aims to identify the learning climate more precisely to the level of innovative work behavior. This analysis test's final result is an equation of the regression line used to 
predict the change through predictor or independent variable. The result of the hypothesis test is shown in Table 4.

Table 4. Result of Research Hypothesis Test

\begin{tabular}{ccccccc}
\hline $\begin{array}{c}\text { Independent } \\
\text { Variable } \\
(\mathbf{X})\end{array}$ & $\begin{array}{c}\text { Dependent Variable } \\
(\mathbf{Y})\end{array}$ & $\beta$ & $\mathbf{p}$-value & $\mathbf{R}$ & $\mathbf{R}^{2}$ & Explanation \\
\hline $\begin{array}{c}\text { Constant } \\
\text { Learning } \\
\text { Climate }\end{array}$ & $\begin{array}{c}\text { Innovative } \\
\text { Work Behaviour }\end{array}$ & $\begin{array}{c}19.838 \\
0.294\end{array}$ & 0.000 & 0.721 & 0.514 & Significant \\
\hline & Source: data that has been processed by the author (2021) &
\end{tabular}

In Table 4, the result of the regression analysis hypothesis test shows that sig. or $\rho$-value is 0.000 . The result indicates that $\rho$-value is smaller $(<)$ than 0.05 , which means that learning climate affects innovative work behavior. Analysis of determination coefficient was conducted to identify the contribution provided by learning climate to innovative work behavior.

It shows that learning climate contributes $51 \%$, which can be seen through formula $\mathrm{R} 2 \times 100 \%$ based on the coefficient of determination (R2) which was 0.514 . This value means that the learning climate contributed $51 \%$ in affecting innovative work behavior, while the rest $49 \%$, was influenced by other variables outside this research. This research shows that $\mathrm{HO}$ is refused. The result of this regression test provides an equation as follows :
$Y=a+b X$ $=19.838+0.294 X$
Explanation:
$\mathrm{Y}=$ Dependent variable
$\mathrm{X}=$ Independent variable
$\mathrm{a}=$ Constant $(\mathrm{Y}$ when $\mathrm{X} 1=0)$
$\mathrm{b}=$ Coefficient of independent variable regression

The regression equation above is interpreted as follows: (1) When the learning climate variable is 0 , innovative work behavior shown by the employees will be -19.838 ; (2) When the learning climate variable increases by 1 point, employees' innovative work behavior is 0.294 .

All employees in a digital start-up company are expected to be work agilely and have an innovative spirit. It performs through a continuous renewal of the organization's idea, process, and procedure to make a new product. One of the work behaviors that affect the regeneration or invention behavior in the form of a new idea, process, development, and strategy is Innovative Work Behaviour (IWB). In Jong \& Hartog (2010) IWB is the interaction between capability owned by individual and system condition applicable in the environment. IWB could be on the potency owned by an individual, consisting of intellectual capacity and psychological condition with interacts with system condition in the environment. The interaction process between the capital in the individual and the state in the environment will encourage IWB. The result of some researches shows some antecedents related to applicable environment system in the organization which affects IWB, namely organizational learning climate Farrell et al (2017) organizational support for innovation (Scott \& Bruce, 1994). Meanwhile, in the individual phase, some antecedents which affect IWB are Educational Level (Ayuni, 2018) Creative Behaviour (Series et al., 2017) Psychological Capital (Series et al., 2017), and Self Efficacy (Luthans et al, 2007). 
This research shows alignment from previous studies in which organizational climate (specifically, learning climate) affects innovation behavior in work, particularly in start-up digital companies. When a company's learning climate is higher, innovative behavior in employees when working is also higher. Organizational Activities in learning climate includes; sharing session and training, freedom of speech in a forum, and leader behavior who can be a role model for the subordinate in learning and searching new knowledge, related to the technology development. In particular, these activities affect the emergence of innovative behaviors, such as exploration, idea generation, championing from idea realization to innovation application in work and company. This digital-based company needs to compile learning management to monitor its employees' development, leading to innovation. Innovation resulted from employees, particularly in a digital start-up company, will contribute to organizational performance. In other words, the more positive the learning climate in the organization as perceived by employees, the more frequencies on innovative work behavior shown by employees will be.

\section{CONCLUSION}

The research result shows that learning climate positively affects innovative work behavior in a digital start-up company. When the company's learning climate is higher, innovative behavior among employees is also getting higher. In other words, the more positive the learning climate in the organization as perceived by employees, the more frequencies on innovative work behavior shown by employees will be.

\section{REFERENCES}

Ayuni, G. F. (2018). Pengaruh Psychological Capital dan Service Climate Terhadap Innovative Work Behavior. Universitas Padjadjaran.

Eldor, L., \& Harpaz, I. (2018). The Nature of Learning Climate in Public Administration: A Cross-Sectorial Examination of Its Relationship With Employee Job Involvement, Proactivity, and Creativity. Journal of Organizational Behavior, https://doi.org/10.1177/0275074018804667

Farrell, Mark., Shanker, Roy., Bhanugopan, Ramudu., Heijden, V. Der. (2017). Organizational Climate for Innovation and Organizational Performance: The Mediating Effect of Innovative Work Behavior. Journal of Vocational Behavior. https://doi.org/10.1016/j.jvb.2017.02.004

Jong, J \& Hartog, D. (2010). Measuring innovative work behavior. Journal Creative and Information Management.

Krueger, N. F. (2000). The Cognitive Infrastructure of Opportunity Emergence. Journal of Business Venturing, 24(3), 5-24.

Loefianti, A. R. (2015). Pengaruh Psychological Capital dan Organizational Innovative Climate Terhadap Innovative Work Behavior. Universitas Padjadjaran.

Luthans, F., Youssef, C. M., \& Avolio, B. J. (2007). Psychological Capital: Developing the Human Competitive Edge. New York: Oxford University Press.

Parker, S. K., Williams, H. M., \& Turner, N. (2006). Modeling the Antecedents of Proactive Behavior at Work Modeling the Antecedents of Proactive Behavior at Work. Journal of Applied Psychology. https://doi.org/10.1037/0021-9010.91.3.636

Scott, S. G., \& Bruce, R. A. (1994). Determinants of Innovative Behavior : A Path Model of Individual Innovation in the Workplace. The Academy of Management Journal, 37(3), 580-607

Series, W. P., Sameer, Y. M., Ohly, S. (2017). Innovative Behavior of Employees: A model of Antecedents and Consequences, A Deeper Look at Psychological and Organizational Factors. 